\title{
A Pilot Study of Accounting Teaching with LMS Platform
}

\author{
Dimitrios Belias, Athanasios Koustelios \\ Department of Physical Education and Sports Science, University of Thessaly, Greece
}

\begin{abstract}
In the past years, the role of the accountant has changed due to the continuous development of the market economy. As we enter the technological era, students and teachers have both changed their methods of learning and acquiring information, making the implementation of ICT technologies in the teaching process of accounting a necessity. In the present study, we propose a research outline of a web based tool for the teaching of accounting in replacement of traditional classroom teaching. The main objectives of the present research are the following: 1) The application of an LMS system as main teaching tool of an accounting course and 2) The comparison of the LMS tool to traditional lecture type teaching method.
\end{abstract}

\section{Introduction}

The economic business of the enterprises has become more complicated, demanding higher skills from the accountants both in theory and practice [1]. Albrecht \& Sacks [2] suggested that the teaching of accounting in universities should keep up with the demands of the global economy. Therefore, a reform of the teaching of accounting is essential, since students need to acquire more skills to achieve the demands of the society. This new competitive environment has launched the universities reform regarding both teaching material and methods [3].

There are various methods for teaching accounting, e.g. reading text, problem solving, interactive lectures, studying case studies, short projects, presentations, stimulation games and roleplaying [4]. The choice of the teaching method is mainly influenced by the instructor's pedagogy and the students' goals [4]. For a long time, teaching methods in accounting were mostly of lecture type in a traditional classroom and teacher centered [5], but this scenery is changing due to the markets demands for high skilled accountants [1].

The implementation of computers and internet in teaching launched the active integration of ICT technologies in education. Soon, computers and ICT technologies were also utilized for teaching accounting. Regarding computers, there are available several software to assist student learning such as productivity software, drill and practice software and simulation software [6]. A useful tool in teaching accounting is also internet with all its provided applications. For instance, on line homework has proven to be a useful tool, as it was shown that motivates students and enhances deep learning and understanding of accounting procedures [7-8].

ICT technologies were firstly introduced in distant learning programs, in order to facilitate the learning process of the adult student. Soon, the potentials of ICT tools caught the attention of traditional classroom instructors [9-10] and virtual learning environment appeared as an education tool [11]. The number of ICT tools that are already used in universities is continuously increasing. Teaching tools like WebCT [12-13], and BlackBoard [14] have already been adopted by education institutes.

Nowadays, both students and teachers have changed their methods of learning and acquiring information, making the implementation of ICT technologies in the teaching process of accounting a necessity. The number of teachers who are using ICT technologies either as auxiliary or as main teaching method is continuously increasing. Many of these new technological tools are not education specific but with the right integration by educators they can become valuable resources for students [6]. Many educators agree that the integration of ICT tools in education has initiated a social change on the teaching pedagogy [15-17].

\section{Objectives}

A learning management system (LMS) is a software application for the administration, documentation, tracking, and reporting of training programs, classroom and online events, e-learning programs, and training content. LMSs range from systems for managing training and educational records, to software for distributing courses over the Internet with features for online collaboration. Student self-service (e.g., self-registration on instructor-led training), the provision of on-line learning (e.g., computer-based training, read \& understand), on-line assessment, management of continuous professional education (CPE), collaborative learning (e.g., application sharing, discussion threads), and training resource management (e.g., instructors, facilities, equipment), are dimensions to Learning Management Systems. Some LMSs are Web-based to facilitate access to learning content and administration and are used by educational institutions to enhance and support 
classroom teaching and offering courses to a larger population of learners across the globe [18-19].

The main objectives of the present research are the following: 1) The application of an LMS system as main teaching tool of an accounting course and 2) The comparison of the LMS tool to traditional lecture type teaching method.

\section{Proposed Methodology}

Participants: The population of this study will be all students from different educational institutes of the city of Thessaloniki: a public Institute of Vocational Training, a Technological Educational Institute, Aristotle university and Hellenic Open university. All students will attend an introductory course in accounting. The control group will be taught by traditional lecture-type of teaching whilst the treatment group will be taught by the LMS platform. The study contains depended and independent variables. The independent variables are teaching material (examples, exercises, homework, e-books, team works etc) and demographic data (kind of institute, age. sex, computing skills, previous knowledge of the platform). The dependent variable is the understanding of the teaching material with the LMS platform.

LMS and teaching material evaluation: According to Elliott [20], the method of triangulation is the best way to fully address an issue. For the data collection we are going to use two methods: interview and questionnaires. Students' opinions about the effectiveness of the teaching method will be recorded with interviews. The effectiveness of the teaching method (traditional or LMS) will be assessed with two questionnaires. The first questionnaire will be completed by both groups and will assess the effectiveness of the teaching method while the second questionnaire will be completed by the treatment group to assess the platform itself (userfriendly, enhanced learning, efficiency, etc).

\section{Discussion of Expected Outcomes}

The proposed research focuses on how a web based learning system will benefit students' learning of accounting. There is strong evidence that the implementation of internet as a teaching tool, enhances deep learning and cultivates skills that are important for the demanding profession of accounting [21].

Boyce has demonstrated that with ICT technologies, teaching material and accounting procedures are taught to students in a realistic manner, which would not be feasible in a traditional classroom. Furthermore, students feel more autonomous and in control of their learning process, thus enhancing active learning. De Lange [12] has shown that students are motivated in learning when it is offered in new and modern ways. On the other hand, if these new technologies are not used with proper care, could lead to misconception of accounting terminology, which could be avoided in traditional classroom [22].

Both internet and virtual learning environment have brought revolution in teaching pedagogy. The majority of students have embraced them as well as the teachers. Their integration in the teaching of accounting may be beneficial but disastrous too. A review of the existing literature, have proved the necessity of the utilization of ICT tools in the teaching of accounting. However, the main question is if all students are being benefited by ICT tools and how these tools can be improved in order to enhance active learning.

To our knowledge, there has not been previously conducted any study on the LMS implementation in the teaching of accounting in Greek institutes. From the outcomes of the study, we hope to clarify whether on line courses enhances students learning compared to traditional classroom or just provides students with extra skills [23]. Furthermore, we hope to get some insight on how to improve LMS system and make it more effective as a teaching tool of accounting.

\section{Conclusions}

One of the consequences of the technological development is the change of learning and teaching process. According to the existent literature, there is strong evidence that LMS integration in the teaching of accounting will benefit students. This proposed research intends to get some insight on how LMS system may promote learning and become a useful teaching tool of accounting.

\section{References}

[1] D.Z. Williams, "Reforming accounting education: The AECC is trying to ensure classroom learning matches realworld needs", Journal of Accountancy, American Institute of Certified Public Accountants, 1993, pp. 76-82.

[2] W.S. Albrecht, R.J. Sack, "Accounting education: Charting the course through a perilous future", Accounting Education Series (Vol. 16), American Accounting Association, Sarasota FL, 2000.

[3] E. Mohamed, S. Lashire, "Accounting knowledge and skills and the challenges of a global business environment", Managerial Finance, Emerald, U.K.2003, pp.3-16.

[4] S. Bonner, "Choosing Teaching Methods Based on Learning Objectives. An Integrative Framework", Issues in Accounting Education, 1999, American Accounting Association, pp. 11-39. 
[5] P.G. Cottel, B.J. Millis, "Cooperative structures in the instruction of accounting", Issues in Accounting Education, American Accounting Association, 1993, pp. 40-60.

[6] G. Boyce, "Computer-assisted teaching and learning in accounting: pedagogy or product?, Journal of Accounting Education, Elsevier, 1999, pp.191-220.

[7] T.M. Lindquist, L.M. Olsen, "How much help, is too much help? An experimental investigation of the use of check figures and completed solutions in teaching intermediate accounting", Journal of Accounting Education, Elsevier, 2007, pp.103-117.

[8] J. Peng, "Using an Online Homework System to Submit Accounting Homework: Role of Cognitive Need, Computer Efficacy, and Perception", Journal of Education for Business, Taylor and Francis, 2009, pp.263 -268.

[9] W. Wade, "What do students know and how do we know that they know it?", Technical Horizons in Education, 1999, pp. 94-97.

[10] S. Liaw, H. Huang, "Enhancing interactivity in webbased instruction: A review of the literature", Educational Technology, 2000, pp.41-45.

[11] Seale, J., and R. R. Mence, An Introduction to Learning Technology within Tertiary Education in the UK, Oxford Brookes University, Headington, UK, 2001.

[12] P. DeLange, T. Suwardy, F. Mavondo, "Integrating a virtual learning environment into an introductory accounting course: Determinants of student motivation", Accounting Education, Taylor and Francis, 2003, pp.1-14.

[13] A.E. Dunbar, "Genesis of an online course", Issues in Accounting Education, American Accounting Association, 2004, pp.321-343.

[14] P. Wells, P. De Lange, P. Fieger, "Integrating a virtual learning environment into a second-year accounting course: determinants of overall student perception", Accounting and Finance, Wiley, 2008, pp.503-518.

[15] R. Donnelly, K. O'Rouke, "What now? Evaluating elearning CPD practice in Irish third-level education", Journal of Further and Higher Education, Taylor and Francis, 2007, pp.31-40.

[16] B.N. Potter, C.G. Johnston, "The effect of interactive on-line learning systems on student learning outcomes in accounting", Journal of Accounting Education, Elsevier, 2006, pp. 16-34.

[17]L.B. Zane, L. Muilenburg, "Design discussion questions for online, adult learning", Educational Technology, 2006, pp.53-56.

[18] R.K. Ellis, "Field Guide to Learning Management Systems", ASTD Learning Circuits, 2009.

[19] M. Aberdour, "Open Source Learning Management Systems”, Epic White Paper, Epic, U.K., 2007, pp.1-38.
[20] J. Elliott, “Action research for school change”, Open University Press, Philadelphia, 1991.

[21] R.R. Kopel, L.W. Dudley, “A beginner's guide to Internet-enhanced financial accounting courses", Advances in Accounting Education, Emerald, U.K., 2003, pp.289303.

[22] D.E. Leidner, S.L. Jarvenpaa, "The use of information technology to enhance management school education: A theoretical view", MIS Quarterly, Management Information Systems Research Center, Carlson School of Management, University of Minnesota 1995, pp.265-291.

[23] S. Watson, B. Apostolou, J. Hassell, S. Webber, "Accounting education literature review (2003-2005)", Journal of Accounting Education, Elsevier, 2007, pp.1-58 